\title{
Article \\ Portuguese Primary and Secondary Education in Times of COVID-19 Pandemic: An Exploratory Study on Teacher Training and Challenges
}

\author{
Susana Henriques ${ }^{1, *(\mathbb{D}}$, Joana Duarte Correia ${ }^{2} \mathbb{C}$ and Sara Dias-Trindade ${ }^{3}(\mathbb{D}$ \\ 1 Centro de Investigação e Estudos de Sociologia (CIES-Iscte), Iscte-Instituto Universitário de Lisboa/ \\ Universidade Aberta (UAb), 1649-026 Lisboa, Portugal \\ 2 Centro de Investigação e Estudos de Sociologia (CIES-Iscte), Iscte-Instituto Universitário de Lisboa, \\ 1649-026 Lisboa, Portugal; Joana_Telma_Correia@iscte-iul.pt \\ 3 Centro de Estudos Interdisciplinares, Faculdade de Letras (DHEEAA), Universidade de Coimbra, \\ 3000-186 Coimbra, Portugal; sara.trindade@uc.pt \\ * Correspondence: Susana_Alexandra_Henriques@iscte-iul.pt
}

Citation: Henriques, S.; Correia, J.D.; Dias-Trindade, S. Portuguese Primary and Secondary Education in Times of COVID-19 Pandemic: An Exploratory Study on Teacher Training and

Challenges. Educ. Sci. 2021, 11, 542.

https://doi.org/10.3390/

educsci11090542

Academic Editors: Jose Ángel

Martínez-López, Cristina

Lázaro-Pérez, José Gómez Galán and

Diego Vergara

Received: 30 July 2021

Accepted: 9 September 2021

Published: 15 September 2021

Publisher's Note: MDPI stays neutral with regard to jurisdictional claims in published maps and institutional affiliations.

Copyright: (c) 2021 by the authors. Licensee MDPI, Basel, Switzerland. This article is an open access article distributed under the terms and conditions of the Creative Commons Attribution (CC BY) license (https:/ / creativecommons.org/licenses/by/ $4.0 /)$.

\begin{abstract}
The discussion about the use of digital technologies in education is not new. However, the COVID-19 pandemic and the total closure of schools around the world, that forced millions of students to attend their classes from home, has demonstrated the importance of this discussion. It has highlighted the need to revisit debates about the interactions between technology and education, and the added value of digital resources to enhance the educational process. This article, based on an exploratory analysis, aims to understand how the transition from face-to-face to digital was accomplished in Portuguese primary and secondary education, namely regarding teacher training and the difficulties experienced during the emergency remote education period. The data analysed in this article were collected through an online questionnaire, disseminated through online social networks, and answered by 136 Portuguese primary and secondary education teachers. The questions focused on this article were open-ended, and the information collected was analysed using content analysis methodology. The results show how teachers have been forced to modify their pedagogical work, the importance of training, and the inherent challenges and critical reflections associated with the process, as well as the opportunities presented in a post-pandemic educational reality.
\end{abstract}

Keywords: teachers; training; technologies; COVID-19; pedagogy; challenges

\section{Introduction}

On 16 March 2020, the structure of the physical classroom in Portuguese schools changed dramatically. Due to the pandemic caused by the COVID-19 virus, the integration of digital technologies in education rapidly became an obligation, when it had previously been a direction followed only by a few. The impossibility of students being physically in schools accelerated an emerging digital transition process in Portugal (Action Plan for the Digital Transition of Portugal), which involved training teachers and responding to the lack of technological resources and poor Internet connectivity. Quick measures led to the development of emergency remote teaching, which was both different and distant from concepts such as digital education or E@D [1].

Even before the pandemic resulting from the COVID-19 virus, several media were already reporting on school and educational systems that were trying to break with traditional views of learning, moving to collective learning environments using technologies. These experiences were already proving that technologies are essential to facilitate the management of autonomy in these contexts, using, for example, project-based learning, blended learning, flipped learning, or active participation of students in various online social spaces. However, in 2020, emergency remote teaching was implemented in a country 
where most schools had not yet effectively integrated digital technologies into a pedagogical strand. Furthermore, the use of such technologies and the associated training necessary for creating an innovative, dynamic, meaningful, and qualitative pedagogical practice was not yet a priority. In this context, digital technology has truly positioned itself as the dominant aspect of literacy, although being digitally competent depends more on a set of knowledge, skills, and attitudes than on access to technologies and knowing how to use them [2]. This was evident in the way teachers dealt with the situation that was forced upon them by the emergency, which required a lot of effort. In some cases, there was a transposition of physical classes to digital environments; in other cases, teachers tried to learn more about digital education in order to put different strategies into practice in their classes.

The pandemic, therefore, demonstrated the need to integrate technology into teachinglearning processes, linking scientific, pedagogical, and technological knowledge, as well as highlighting the need for adequate tools and resources. This is essential in order to be able to adjust pedagogical models and practices to the needs of contemporary and future students, who may even have jobs that do not exist yet, as they live surrounded by digital technologies. Students tend to be unable to learn without technologies, but they have to learn how to pedagogically interact with them and need to not only acquire knowledge, but also develop learning skills, thus helping them to achieve professional and personal success. It is important to highlight these processes with further research centred on the actors involved: teachers and students.

In this scope, this paper presents an exploratory study aiming to understand how the transition from face-to-face environments to virtual ones was made in primary and secondary education in Portugal, namely regarding how teachers felt and how they reacted to the sudden change, as well as how post-pandemic education in Portugal will be affected by this experience.

\section{Education and the Pandemic in Portugal: Embedding Digital Thinking in Schools}

The beginning of 2020 saw the emergence of a pandemic that caused disturbances at different levels in schools all over the world. In Portugal, people in society, and schools in particular, do not have equitable access to digital technology. This issue developed new contours, as the pandemic exposed the need to focus on areas of digital literacy, digital skills, and digital fluency.

Facing the need of a transition to an emergency remote education [1], the weaknesses of an entire system based on digital technologies and resources became more evident, showing the importance of having digital skills in different areas of teaching practice [3]. In a country with different rates of technological connection, it was clearly seen that an education empowered by digital technology was still an idea under construction.

Given the centralised organisational characteristics of school administration and management [4], the Portuguese Ministry of Education, through the Directorate General of Education, took on the preparation of a set of guidelines and training actions aimed at teachers. Such initiatives were designed to support teachers in the transition from a face-to-face education model to a completely virtual one, seeking, in parallel, to support students who did not have access to technological devices or Internet connectivity [5].

In this context, the Portuguese Council of Ministers approved the Action Plan for Digital Transition, which is assumed to be "the country's transformation engine" [6] (p. 8), and which aims to put into practice a diverse set of measures to provide the country's digitalisation. These measures are organised into three main pillars, the first one being dedicated to training and digital inclusion that includes digital education and requalification.

Within the scope of digital education, one of the objectives of youth training is the "transversal integration of technologies in the different curricular areas of basic and secondary education" [6] (p. 15). This objective refers to a transversal training, suitable to the skills for the 21st century, where the role of technology, as already mentioned in 2015 by the World Economic Forum [7], will be fundamental to ensure social and professional 
equity for everyone in the world. The sub-pillar on professional requalification and training specifies teacher training among the measures to be adopted which will be essential for effective integration of technologies in educational practices.

The goals for the Portuguese school are in line with the idea of a digital school, where the teaching and learning processes are increasingly enriched by digital technologies, and where humans and non-humans interact collaboratively, in order to teach, learn, and build knowledge in an active and participatory way, thus making use of digital technology to bring "students closer to the productivity and collaboration tools that they can find in a professional work environment" [6] (p. 15).

The Ministry of Education (under the collaboration between the General Directorate of Education and the National Agency for Qualification and Vocational Education) created a supportive website for schools, which made a set of documents, guidelines, and resources available to the whole educational community, especially to teachers and headmasters. Moreover, a direct communication channel between schools and the Directorate General for Education was created through electronic mail, with the aim of providing a rapid response to queries and further support in the face of difficulties.

One of the first documents to be made available was the Roadmap -8 guiding principles for the implementation of Distance Learning (E@D) in Schools [8] which embodies a support tool for the "design of the best strategy and Plan for Distance Learning (E@D)". This generic document included the recommendation of the E@D Plan to be adapted according to the specificities of the school and social context, as well as the available resources. Without detailing the eight points that make up the Roadmap for the development of the E@D Plan, it is worth mentioning that it contains support for a rapid response to crisis, ensuring that instructional activities can be delivered remotely. Schools had to make their decision-making processes faster, without time for "the completion of fundamental steps for distance education initiatives to be successful. Steps such as planning, training of all involved, preparation of the technological infrastructure (hardware and software) ( ... ) inclusion" [9] (p. 8). The result was, in general, the development of a set of methodologies and essentially expository practices, technologically mediated, and closer to the characteristics of emergency remote education than to distance education.

In another axis of the intervention are the training actions, the number of which increased exponentially, with some actions being more formal than others. Teachers attended on their own initiative or via proposals from a range of agencies including the organisation of the school or grouping, training centres of school associations, publishers, software companies, or even from offers that resulted from the organisation of the Ministry of Education through the Directorate General of Education. In this last group is the training course for Digital Networked Education, from a partnership between the Directorate General of Education (DGE in the Portuguese acronym) and the Portuguese Open University. This course was designed with the aim of promoting skills in the area of distance education in a double dimension, in primary and secondary school teachers: helping them to overcome the limitations imposed by the pandemic, but also promoting the development of "a new paradigm of a more hybrid education" [9] (p. 8).

In fact, the OECD [10] also identified this moment as an opportunity to change the predominant trend of teaching based on exposure and learning based on the passive reception of knowledge- a trend present in Portugal, which neglects ways to interact, question, and experiment. Thus, it is an opportunity for experimentation and the development of new models of education and new ways to make the most of face-to-face learning time. Specifically, four priority axes were identified: the exploration of secure systems for home-based assessment tests; the exploration of different models of time and schooling; the empowerment of teachers to make the most of digital advancement; and the use and monetisation of variations within and across countries for learning [10] (p. 3).

Under the Digital Transition Action Plan, the Government has defined the provision of individual equipment and free connectivity for both students and teachers, access to quality educational resources, and a strong focus on the digital training of teachers. Thinking about 
the current events, but also a post-pandemic education, a teacher training process is now underway, following a policy that DGE has been defending for some years: specialised training, with a strong practical component and a schedule that allows teacher trainees to understand the training contents and put them into practice. Furthermore, it helps them to understand existing doubts and acquire new and relevant knowledge through practice and collaboration. This is pertinent, considering the point that was raised early in this article about the importance of training that contributes to an effective development of new skills.

The training prepared by the DGE, which included the participation of experts from various Portuguese universities (the Portuguese Open University, University of Évora, University of Lisbon), initially involved the training of trainers throughout the country, who were subsequently responsible for disseminating this training to the training centres network (CFAE in the Portuguese acronym) throughout the country. In this stage of training, all teachers were asked to answer the DigCompEdu CheckIn questionnaire so that they could be placed in level 1 or level 2 classes, depending on the results obtained.

The strong investment in teaching digital training also included the publication of the Order No. 2053/2021, which established that every training action carried out since March 2020 in the scope of a Digital Education is "exceptionally, considered as carried out in the scientific-pedagogical dimension of all recruitment groups" [11] (pp. 109-110). At the same time, each school should, in collaboration with its training centre and through its digital ambassadors, define a set of actions aimed at preparing its Digital Development Action Plan (PADD acronym in Portuguese). This elaborate pedagogical network which articulates the DGE, the CFAE, the schools, and the entire educational community should achieve an in-depth preparation, implementation, monitoring, and evaluation between 2021 and July 2023.

Further research is therefore required to understand these processes and our study intends to be a contribution. The research question guiding our exploratory study regards how the transition from face-to-face environments to virtual ones was made in primary and secondary education in Portugal. Namely, it is our goal to focus on teachers' perspectives about their feelings and reactions to the sudden changes and how post-pandemic education in Portugal will be affected by this experience.

\section{Methodology}

\subsection{Study, Data Collection, and Participants}

The data used in this article set up an exploratory study and are the results of an online questionnaire, comprising 15 questions. The questionnaire was disseminated through online social networks and answered between April and August 2020. Respondents were 136 Portuguese primary and secondary education teachers, from both public and private schools geographically dispersed across mainland Portugal and its islands. Neither age nor gender were asked of participants, as other studies related to education and digital competences indicate that there are several factors that affect the greater or lesser teaching digital competence and that motivation and training are more relevant than age, gender, or even basic scientific area [12-14].

This method of recruitment was chosen since schools were closed during the data collection period. In the middle of the pandemic, the use and importance of online social networks increased, to the extent that several new communities were formed and/or strengthened with the purpose of supporting teachers in the remote teaching responses they were forced to develop (e-Learning Facebook support, for example).

The use of online questionnaires has increased as a result of the constraints imposed by the COVID-19 pandemic. The use of social media has revealed its potential for recruiting samples in research [15].

In this context, the present data collection process fits with others that have sought answers to the urgent need for new data collection strategies, with important advances in methodological development and with evidence of low bias in the data [16]. 
The larger questionnaire designed for the research aimed to understand the use of digital resources and environments for education purposes. The questions presented reflect four dimensions that were deemed relevant to characterise Portuguese teachers' perceptions of the transition to emergency remote education in the time of pandemic COVID-19. The dimensions were: (a) type of digital platforms used; (b) school and teacher training strategies; (c) digital divide; and (d) analysis of specific cases. For this article, we focused only on part of the findings, namely, the questions related to: (1) the ability to work with digital learning environments after the emergency pandemic remote experience, and (2) to the major difficulties faced by our respondents. Those questions were open-ended and the information collected was analysed with content analysis methodology [17,18]. The content analysis had two dimensions: the first one was conceptual analysis, aiming to identify the occurrence of selected terms in the data; the second one was relational analysis, aiming to identify relationships between such concepts and their meanings.

\subsection{Project Ethics}

The research project that this article is based on is in line with the Ethical Charter published by the Portuguese Society of Education Sciences [19] and follows the guidelines linked to it. As argued by [20], the investigative process was always associated with high levels of vigilance and self-reflection regarding ethical issues.

The respondents' participation was voluntary, with the option of withdrawing from completing the questionnaire at any time [21]. Responses were anonymous and data were worked up together, with the results used only to address the objectives of the current research $[21,22]$.

As stated by [23], the publication of these results takes on the strategic nature of information dissemination, as this is the best way to share knowledge in research where there is effectively no administrative record of the sample or contact with respondents (we recall that data collection was done online, through social media). It is therefore an integrated approach to data collection using non-probability, convenience sampling, taking advantage of the powerful segmentation resources of social networks and their virtual communities [15].

The data collected and the results obtained do not represent any type of restraint for the participants [24], with the authors assuming that the study of the contexts and practices of Portuguese teachers' performance during the pandemic resulting from the COVID-19 virus may translate into an outstanding contribution to the field of educational research.

\section{Results and Discussion}

\subsection{Teacher Training Regarding the Use of Digital Resources and Environments for Education}

The survey included questions on teacher training regarding the use of digital resources and environments for education. When asked about specific training in this area before the pandemic lockdown, $67.7 \%$ answered affirmatively. These figures indicate that still about one third of teachers had not participated in any training in the area of educational technologies. This corresponds with a working class that mostly did its initial training more than 20 years ago (the average age of a Portuguese teacher is 49 years [25], a period during which digital learning was still largely unused in Portuguese schools and almost non-existent in the initial training of teachers).

This reality meant that many teachers, faced with the technological evolution that in the last 20 years has brought new equipment, new resources, and, above all, new possibilities into the school in a hyperconnected and multimodal world, needed to seek training that would give them the confidence to innovate. This is in line with the indices of confidence in an operational use of digital technologies (considered fundamental skills for a generic use of digital resources) presented in the 2013 European Commission report, which placed Portuguese teachers with high levels of confidence and always above the European average itself. It also highlighted the importance of training in increasing confidence levels, 
stating that there are positive correlations between confidence in operational skills for the use of digital technologies and participation in training for professional development [26].

However, by itself, teacher training in this area is not enough to enable professionals to make suitable use of digital technologies, even if it was part of their initial training or if they feel confident in its use. In the PISA 2021 report [27], it was indicated that there is evidence that younger teachers still have some inexperience regarding the pedagogical uses that can be given to different technologies, while older teachers sometimes lack the technical knowledge to use technology to enhance learning.

Ref. [28] points out that "spreading the Internet or putting more computers in schools does not necessarily constitute major social changes" (p. 19). In fact, with the social evolution and the new requirements for education, as well as the constant innovation of technology, it is essential to critically reflect on the new ways of working of the teacher $[29,30]$. It always requires a solid articulation between pedagogy and technology, because "technology can amplify good teaching, but good technology cannot replace bad teaching" [31]. Moreover, the higher the level of teacher confidence in digital areas, the greater the capacity for effective integration of technologies in educational environments [32].

In Portugal, even in recent years, it has not been mandatory to have curricular units related to educational technologies, although there is reference in Portuguese legislation to the need for general educational training to include all relevant knowledge for a good teaching performance in the classroom [33]. If the investment on initial teacher training is still not a reality - it being up to each university to define its curriculum project and how it includes educational technologies in the preparation of future teachers-in continuing education, digital technologies training has been considered a priority, especially since 2007 [34]. This is the result of an awareness that the lack of preparation leads to a basic, conservative, or instrumental use of technologies in the classroom.

In a period of emergency remote education, results show teachers' awareness on the need for more as the vast majority of primary and secondary school teachers had no specific preparation for digital educational environments. In this sense, it is unsurprising that $79.4 \%$ of the participants in this study mentioned that they felt the need to do more training, since the pandemic forced the physical closure of Portuguese schools. Although $10 \%$ of the respondents were still not feeling prepared for teaching in digital environments, $90 \%$ of them stated that they are more prepared now. However, many of those teachers discussed weaknesses, threats, and future fears. Challenges related to technology, pedagogical changes, governmental guidelines, and individual needs of students implied that teachers felt unprepared:

"Distance Learning requires training";

"Very exhausting. Constant failures in the net, in the sound, in the image, etc.";

"The distance does not allow the consolidation of the contents nor the real perception of the students' acquisition of learning. In-presence is essential".

As mentioned by [5], this situation promoted a "learning by doing" opportunity for teachers. Therefore, this is a moment in which the past and the future are envisaged, and new and assertive steps are taken towards change and innovation. The Portuguese Government's plan for school digital training, which had already started before the pandemic crisis, develops training based on the DigCompEdu framework, aiming to give them time to learn and gradually start to incorporate digital resources in teaching practices.

In addition, the preference for training programmes with a longer duration is also frequent, because it allows a better understanding of the effects over the teaching practices. Several pieces of research show that trainees begin to modify their practices, promoting more active and dynamic classes and using technologies as a means for the development of innovative, dynamic, and active learning strategies [35-37]. However, these authors consider these changes to be slow processes that need "a certain maturation to generate transformation" [36] (p. 222). 
It is worth noting some responses, which stressed that those who already used digital technologies frequently managed to make the transition to emergency remote education with greater security:

"As I am an ICT teacher, I already had the skills and used the E@D platform";

"Because I previously worked with digital educational environments";

"I was ready and willing that one day this could happen in a public school. We evolved 10 years in just 2 months".

\subsection{Difficulties Faced by the Education Community}

Furthermore, some difficulties emerged regarding the students' conditions in line with [38,39]. Inequalities, socio-economic differences, and family conditions of the students; lack of assistance, support, or supervision by an adult or guardian; lack of equipment and Internet connection; lack of knowledge of tools and software (by students, teachers, and parents); or lack of information emerged as the biggest problems identified by the respondents:

"The detachment, because most students don't even turn on the webcam and don't have the same pace of work. Students said they missed school";

"Not feeling the presence of the student";

"To see if the students were really attentive and to detect doubts, because they never manifest themselves online"

"Students don't have all the resources they need!"

Regarding these major difficulties experienced by teachers during the pandemic crisis and the lockdown, in Portugal, the situation was similar to that of most European countries. As one of the OECD reports states, "this crisis has exposed the many inadequacies and inequities in our education systems-from access to the broadband and computers needed for online education, and the supportive environments needed to focus on learning, up to the misalignment between resources and needs" [10] (p. 4).

\subsection{Transitions to Virtual Learning Environments}

Relational analysis is a kind of content analysis that allows us to identify four main concepts, which have different related categories (see Figure 1). The main conceptual categories are: remote teaching, regarding the rapid move of teaching to digital environments [1]; engagement and motivation, related with the idea that a student's acquisition of knowledge is mainly dependent on teachers, their presence, their planning, and their activities [40]; technological issues, because technology supports systems and digital networks in these new teaching ecosystems [9]; and personal issues as the teaching presence is a basic element in guiding the acquisition of information and the construction of knowledge [41].

These responses show that teachers have been overwhelmed with the task of providing remote learning opportunities to their students. As stated by one of the respondents, "the management of the different tasks, especially regarding the management of the different situations of students' access to the digital and the feedback to be provided to all students" increased stress situations, just as remarked by [42].

Many had to learn how to use new digital tools in a couple of days as well as rethinking their teaching methodologies. The pandemic exacerbated pre-existing problems, mainly because it forced rapid, "drastic" changes as referred to by the Portuguese Minister of Education himself [43] (p. 4). Furthermore, one study [44] stated that their participants used expressions such as "chaos, panic, worry, apprehension, insecurity, and, above all, uncertainty" (p. 547) to refer to a situation that dictated that education must be continued in exclusively digital environments. Just as one of the participants in this study stated, "not feeling the presence of the student" was the biggest problem for content consolidation and learning development [45], indicating that "as teachers were concerned about enabling students to access a substantial part of the school year's curriculum content from home, the 
introduction of (new) learning content to stimulate students' cognitive activation emerged as another challenge" (p. 613).

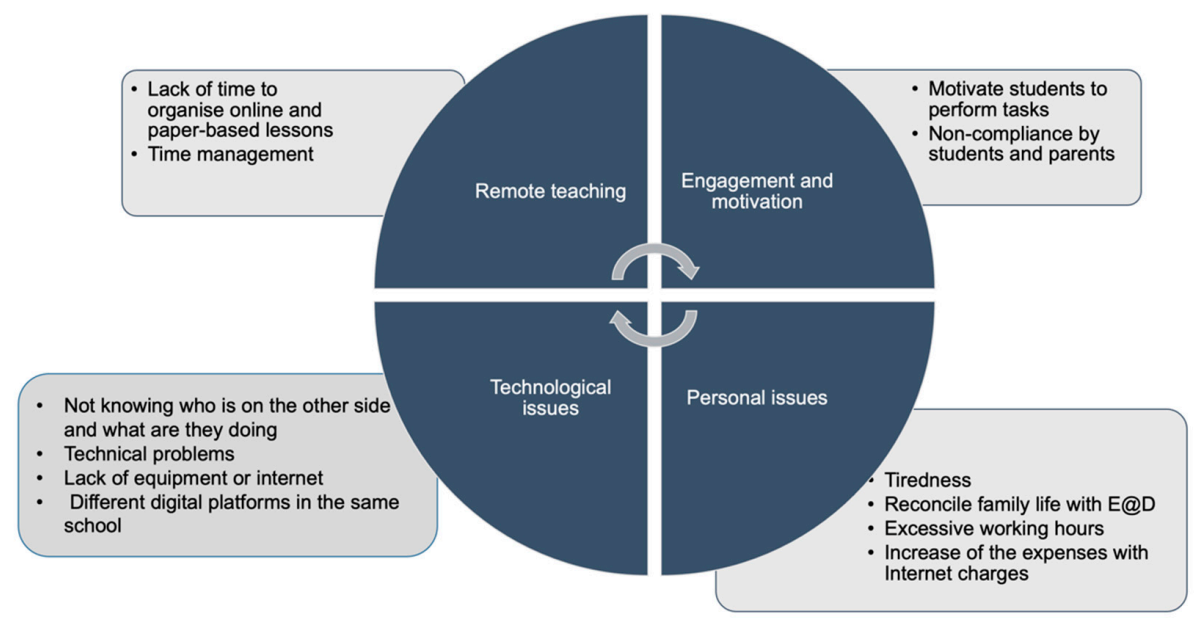

Figure 1. Relational analysis.

Ref. [43] stresses changes in the way students interact and a decrease in motivation for learning. Ref. [44] also reported the impersonal side of an education that does not allow physical contact among the whole school community, and that it is very difficult to manage the difficulties that students may have (either at school or even family level). This distancing is aggravated by the difficulty of interacting with students who keep their cameras turned off, as one of the participants mentions; this was also pointed out by [46] and by [47].

In fact, both the studies by [48,49], among others, state that school activities mediated only by digital mechanisms tend to be less fruitful than those that are interconnected with a physical experience, in schools. In recognizing this issue, it is important to realize that teachers acknowledged that this emergent teaching period can and should focus on the development of transferable skills, and on care for the students' socioemotional connection, whilst still trying to promote the development of knowledge.

All the responses related to the difficulties experienced depicted the same scenario: some schools were well equipped with the necessary infrastructure, devices, and staff, while others had been entirely unprepared to cope with the challenge of offering digital education. Equally, not all teachers and students had sufficient access to digital equipment or a reliable internet connection at home. At the same time, some teachers and students faced great difficulties to access and to deal with online educational resources. As new digital challenges emerged, teachers and students not only had to quickly acquire new knowledge and skills, but they also had to spend considerable time in front of screens. This reality potentiates issues such as those concerning the difficulty in combining family duties with professional duties, problems with time management, and excess work.

\subsection{Limitations}

The study provided wide views on the transition process from face-to-face teaching to remote teaching due to the pandemic crisis. As the respondents are not a representative sample, the results cannot be generalizable.

Applying an online questionnaire using social media network can bring some similarity bias. Nevertheless, the use of online questionnaires has strengths and weaknesses that have been critically analysed in various studies, which highlighted their advantages [50]. Other studies have focused on comparisons with traditional 'pen and pencil' methodologies [51]. 


\section{Conclusions}

In this exploratory study, the results revealed that the context arising from the COVID19 pandemic forced Portuguese teachers to modify their pedagogical work and the teachinglearning process, moving from face-to-face teaching to emergency remote teaching, mediated by digital technologies, and shows that what Portuguese teachers have felt, in dealing with this sudden transition, was like that of many other teachers in the world [3,43-45]. This process evoked several challenges: adaptation and flexibility in relation to a new way of teaching and learning, the use of digital technologies in education, how to motivate and involve students, and school institutional positions. The difficulties experienced in this rapid transition from face-to-face to digital environments, which are manifested in the answers given by several teachers surveyed in this study, reflect what [52] had already pointed out in his work before the pandemic began, namely the teachers' lack of digital knowledge and skills, the lack of technological equipment, and the students' own lack of digital skills.

The difficulties faced by teachers and the (lack of) ability to work with digital learning environments shows the importance of training in educational technologies, as also stated by [44]. However, it is not enough to attend teacher training in this area to enable these professionals to make suitable use of technologies. Teachers are an essential part of education and it is necessary to train them not only in face-to-face pedagogy, but also in digital learning pedagogy. Different skills should be trained towards student engagement, teacher performance, and ensuring academic integrity. Open models, hybrid models, and leverage personalization of curricula may well be the answer.

Furthermore, the relationship with students and how it was affected by physical distance, which several participants reported hindered motivation to continue learning, has also been seen in other work, such as in [45]. In fact, both the studies by [48,49], among others, state that school activities mediated only by digital mechanisms tend to be less fruitful than those interconnected with a physical experience in schools.

These difficulties demonstrate the need to think beyond the natural psychological issue, regarding the social isolation to which Portuguese young people, like so many other millions of students around the world, were subjected to during the period of almost total closure of the country, and how the transposition from face-to-face environments to digital environments that occurred in most schools [44] may have contributed to increasing this feeling of demotivation. In fact, this reiterates the importance of digital training for both teachers and students, so that in similar situations it is possible to move from emergency remote teaching to a true networked digital education [9].

The pandemic has emphasised the need to further invest in the development of digital skills for all citizens. Clearly, more professional development opportunities focused on digital technologies and digital literacy for teachers need to be created. While awareness of its importance has grown among teachers as well as policymakers, there remains work to be done to ensure that the problems brought to light are properly addressed-especially as issues preceding COVID-19 underpin the weaknesses of the education sector all over the world. If we have not managed to respond before, let this extreme pandemic situation and all the difficulties felt by the educational communities (represented in this article by teachers) allow us to give shape, through training and empowerment, to learning ecosystems powered by digital technology.

Author Contributions: All authors contributed to the design and implementation of the research, to the analysis of the results, and to the writing, review, and editing of the manuscript. All authors have read and agreed to the published version of the manuscript.

Funding: This paper was published with the support of the Portuguese Government, through the Strategic Funding of the RD Unit UIDB/03126/2020.

Institutional Review Board Statement: Ethical review and approval were waived for this study, due to the fact that the research project that this article is based on is in line with the Ethical Charter published by the Portuguese Society of Education Sciences and follows the guidelines linked to it. 
Informed Consent Statement: Informed consent was obtained from all subjects involved in the study.

Data Availability Statement: The data presented in this study are available on request from the corresponding author.

Conflicts of Interest: The authors declare no conflict of interest.

\section{References}

1. Hodges, C.; Moore, S.; Lockee, B.; Torrey, T.; Bond, A. The Difference between Emergency Remote Teaching and Online Learning. 2020. Available online: https:/ / bit.ly/3fX5bOp (accessed on 14 June 2021).

2. Ala-Mutka, K. Mapping Digital Competence: Towards a Conceptual Understanding. JRC Tech. Notes 2011. [CrossRef]

3. Reimers, M.F.; Schleicher, A. A Framework to Guide an Education Response to the COVID-19 Pandemic of 2020; UNESCO: Paris, France, 2020.

4. Torres, L.M. A escola como entreposto cultural: O cultural e o simbólico no desenvolvimento democrático da escola. Rev. Port. Educ. 2018, 21, 59-81. [CrossRef]

5. Dias-Trindade, S.; Correia, J.D.; Henriques, S. O Ensino Remoto Emergencial na educação básica Brasileira e Portuguesa: A perspetiva dos docentes. Rev. Tempos Espaços Educ. 2020, 13, 1-23. [CrossRef]

6. Council of Ministres. Resolução do Conselho de Ministros n. 30/2020. Diário República, n. 123/2020, Série I, 2020, 6-32. Available online: https: / / dre.pt/home/-/dre/132133788/details/maximized (accessed on 14 June 2021).

7. WEF-World Economic Forum. New Vision for Education: Unlocking the Potential of Technology; World Economic Forum: Cologny, Geneva, Switzerland, 2015.

8. Ministry of Education. Roteiro: 8 Princípios Orientadores para a Implementação do Ensino a Distância (E@D) nas Escolas. 2020. Available online: https:/ / bit.ly /3yNqhr2 (accessed on 14 June 2021).

9. Moreira, J.A.; Henriques, S.; Barros, D. Transitando de um ensino remoto emergencial para uma educação digital em rede, em tempos de pandemia. Dialogia 2020, 34, 351-364. [CrossRef]

10. OECD-Organization for Economic Cooperation and Development. Education Responses to COVID-19: Embracing Digital Learning and Online Collaboration. OECD 2020. Available online: https:/ / bit.ly/3vAqYSC (accessed on 14 June 2021).

11. Cabinet of the Deputy Secretary of State for Education and the Secretary of State for Education. Order n. 2053/2021, Diário República, n. 38/2021, Série II 2020, 109-110. Available online: https:/ /www.gov.uk/government/ministers/secretary-of-statefor-education (accessed on 14 June 2021).

12. Briggs, C.; Makice, K. Digital Fluency: Building Success in the Digital Age; SociaLens: Bloomington, IN, USA, 2012.

13. Dias-Trindade, S.; Moreira, J.A. Assessment of high school teachers on their digital competences. MAGIS Rev. Int. Investig. Em Educ. 2020, 13, 1-21.

14. Gorozidis, G.; Papaioannou, A.G. Teachers' motivation to participate in training and to implement innovations. Teach. Teach. Educ. 2014, 39, 1-11. [CrossRef]

15. Schneider, D.; Harknett, K. What's to Like? Facebook as a tool for survey data collection. Sociol. Methods Res. 2019, 1-33. [CrossRef]

16. Kohut, A.; Keeter, S.; Doherty, C.; Dimock, M.; Christian, L. Assessing the Representativeness of Public Opinion Surveys. The Pew Research Center for the People and the Press. 2012. Available online: https:/ /www.pewresearch.org/politics/2012/05/15 /assessing-the-representativeness-of-public-opinion-surveys/.

17. Selvi, A.F. Qualitative Content Analysis; Routledge: London, UK, 2019.

18. Bardin, L. Análise de Conteúdo; Edições 70: Coimbra, Portugal, 1995.

19. SPCE-Sociedade Portuguesa de Ciências da Educação. Carta Ética; SPCE: Lisboa, Portugal, 2020.

20. Mainardes, J.; Carvalho, I. Autodeclaração de princípios e de procedimentos éticos na pesquisa em Educação. In ANPEd-Associação Nacional de Pós-Graduação e Pesquisa em Educação. Ética e Pesquisa em Educação; Subsídios; ANPEd: Rio de Janeiro, Brasil, 2019 ; pp. 129-132.

21. Bassey, A.; Owan, V.J. Ethical issues in educational research, management and practice. In Encyclopedia of Instructional Leadership, Policy, and Management; Ololube, P.N., Nwivi, G.U., Eds.; Pearl Publishers International: Port Harcourt, Nigeria, 2019 ; pp. $1287-1301$.

22. Creswell, J.W. Projeto de Pesquisa: Métodos Qualitativo, Quantitativo e Misto; Artmed: Porto Alegre, Brasil, 2007.

23. Beardsley, M.; Santos, P.; Hernández-Leo, D.; Michos, K. Ethics in educational technology research: Informing participants on data sharing risks. Br. J. Educ. Technol. 2019, 50, 1019-1034. [CrossRef]

24. Linder, C.; Farahbakhsh, S. Unfolding the Black Box of Questionable Research Practices: Where is the line between acceptable and unacceptable practices? Bus. Ethics Q. 2020, 30, 335-360. [CrossRef]

25. General Directorate of Education and Science Statistics. Perfil Do Docente 2018/2019; DGEEC: Lisboa, Portugal, 2019.

26. European Commission. Survey of Schools: ICT in Education: Benchmarking Access, Use and Attitudes to Technology in Europe's Schools; Publications Office of the European Union: Luxembourg, 2013.

27. TALIS 2018 Results (Volume I): Teachers and School Leaders as Lifelong Learners; OECD-Organization for Economic Cooperation and Development: Paris, France, 2019. [CrossRef]

28. Castells, M. A Sociedade em rede: Do conhecimento à política. In A Sociedade em Rede. Do Conhecimento à Acção Política; Castells, M., Cardoso, G., Eds.; Imprensa Nacional Casa da Moeda: Lisboa, Portugal, 2006; pp. 17-30. 
29. Goeman, K.; Elen, J.; Pynoo, B.; van Braak, J. Time for action! ICT Integration in Formal Education: Key Findings from a Region-wide Follow-up Monitor. TechTrends 2015, 59, 40-50. [CrossRef]

30. Rodrigues, A.L. Digital technologies integration in teacher education: The active teacher training model. J. e-Learn. Knowl. Soc. 2020, 16, 24-33.

31. Students, Computers and Learning: Making the Connection. In Students, Computers and Learning: Making the Connection; OECD-Organization for Economic Cooperation and Development: Paris, France, 2015. [CrossRef]

32. Area-Moreira, M.; Hernández-Rivero, V.; Sosa-Alonso, J.-J. Models of educational integration of ICTs in the classroom. Comunicar 2016, XXIV , 79-87. [CrossRef]

33. Ministry of Education and Science. Decreto-Lei n. 79/2014, Diário República, n. 92/2014, Série I 2014, 2819-2828. Available online: https:/ / mon.gov.ua/eng (accessed on 14 June 2021).

34. Ricoy, M.C.; Couto, M.J.V.S. As TIC no ensino secundário na matemática em Portugal: A perspectiva dos professores. Rev. Latinoam. Investig. Matemática Educ. 2011, 14, 95-119.

35. Montez, R.; Aires, M.L.L. Colaboración online, formación del profesorado y TIC en el aula: Estudio de caso. Teoría Edicación: Educ. Y Cult. Soc. Inf. 2013, 14, 277-301.

36. Sampaio, P. Desenvolvimento profissional dos professores de Matemática: Uma experiência de formação em TIC. Rev. Port. Educ. 2016, 29, 209-232. [CrossRef]

37. Carlos, V.; Pombo, L.; Loureiro, M.J. Integração pedagógica das TIC no contexto de um Edulab reflexão e sistematização de princípios orientadores de boas práticas (projeto AGIRE). Investig. Práticas 2018, 8, $22-41$.

38. Seabra, F.; Mouraz, A.; Abelha, M.; Henriques, S. Equidade e inclusão nas políticas de educação: Perspetivas a partir dos relatórios de Avaliação Externa de Escolas. Indagatio Didact. 2020, 12, 99-117. [CrossRef]

39. Ministry of Education. Orientações para o Trabalho das Equipas Multidisciplinares de Apoio à Educação Inclusiva na Modalidade E@D. 2020. Available online: https:/ / bit.ly /2SA3gau (accessed on 26 July 2021).

40. Bates, A.W. Teaching in a Digital Era. 2019. Available online: https:/ / bit.ly/3uxlDKr (accessed on 26 July 2021).

41. Garrison, D.; Anderson, T.; Archer, W. Critical Inquiry in a Text-Based Environment: Computer Conferencing in Higher Education. Internet High. Educ. 2020, 2, 87-105. [CrossRef]

42. Pascoal, R.M. Acceptance of Online Education in Portugal and in the World: Before and During Covid-19. Kriativ-Tech 2020, 8, 1-7. [CrossRef]

43. Di Pietro, G.; Biagi, F.; Costa, P.; Karpiński, Z.; Mazza, J. The Likely Impact of COVID-19 on Education: Reflections Based on the Existing Literature and International Datasets; EUR 30275 EN; Publications Office of the European Union: Luxembourg, 2020. [CrossRef]

44. Kidd, W.; Murray, J. The Covid-19 pandemic and its effects on teacher education in England: How teacher educators moved practicum learning online. J. Teach. Educ. 2020, 43, 542-558. [CrossRef]

45. König, J.; Jäger-Biela, D.; Glutsch, N. Adapting to online teaching during COVID-19 school closure: Teacher education and teacher competence effects among early career teachers in Germany. Eur. J. Teach. Educ. 2020, 43, 608-622. [CrossRef]

46. van der Spoel, I.; Noroozi, O.; Schuurink, E.; van Ginkel, S. Teachers' online teaching expectations and experiences during the Covid19-pandemic in the Netherlands. Eur. J. Teach. Educ. 2020, 43, 623-638. [CrossRef]

47. Flores, M.A.; Gago, M. Teacher education in times of COVID-19 pandemic in Portugal: National, institutional and pedagogical responses. J. Educ. Teach. 2020, 46, 507-516. [CrossRef]

48. Zhou, L.W.; Shanshan, Z.M.; Li, F. 'School's Out, But Class' On', The Largest Online Education in the World Today: Taking China's Practical Exploration During The COVID-19 Epidemic Prevention and Control As an Example. Best Evid. Chin. Educ. 2020, 4, 501-519. [CrossRef]

49. Almeida, B.O.; Alves, L. Letramento digital em tempos de COVID-19: Uma análise da educação no contexto atual. Debates Educ. 2020, 12, 1-18. [CrossRef]

50. Evans, J.R.; Mathur, A. The value of online surveys. Internet Res. 2005, 15, 195-219. [CrossRef]

51. Lonsdale, C.; Hodge, K.; Rose, E.A. Pixels vs. Paper: Comparing Online and Traditional Survey Methods in Sport Psychology. J. Sport Exerc. Psychol. 2006, 28, 100-108. [CrossRef]

52. Gonçalves, V. COVIDados a inovar e a reinventar o processo de ensino-aprendizagem com TIC. Pedagog. Ação 2020, 13, 43-53. 